\title{
Exploring the Contribution of a Changing External and Internal Organizational Context to the Innovation of Large Organizations
}

\author{
Slavica Tomić, Maja Strugar Jelača, Agneš Boljević \\ University of Novi Sad, Faculty of Economics Subotica, Department of \\ Management, Segedinski put 9-11, 24000 Subotica, Serbia \\ e-mail: tomics@ef.uns.ac.rs; m.strugar.jelaca@ef.uns.ac.rs; \\ aboljevic@ef.uns.ac.rs
}

\begin{abstract}
The aim of this study is to establish the relationship between the degree of an organizations' innovation and external dimensions, taking into account the dynamics of fluctuations from the environment together with the characteristics of organizations, implemented incremental management innovations and realized business results. The object of the research is the analysis of a changeable contextual frame of innovation in large organization systems. While doing the research, we observed the performance of large organizational systems during 2012 and 2013, depending on the fluctuations of external and internal factors that influence innovation. A random sample of 50 large organizational systems, in the territory of the Republic of Serbia was used, which represents $5 \%$ of the base number and covers all regions and business sectors. During the testing of set hypotheses, we used the following statistical methods: ANOVA, MANOVA, and the Kruskal-Wallis tests. The research results indicate the existence of the difference in innovation degree, depending on consumers' preferences, as external dimension and number of employees, values of operating income and operating assets as internal dimension, as well as, a statistically significant correlation between entrepreneur-oriented managerial behavior as an aspect of management innovation and organizations' innovation.
\end{abstract}

Keywords: contextual perspective; institutional changes; entrepreneur-oriented managerial behavior; organization's innovation

\section{Introduction}

Innovation is of fundamental importance for improving organizational performance and the very survival of an organization [13, 42]. It also represents a necessary and natural part of modern business concept in order to make maximum 
use of the positive changes that lead to progress and development at the level of organizations, state and society. The research focuses on the impact of turbulent developments, from the external environment, on the degree of organizations' innovation, as well as, the influence of changing internal organizations' context through characteristics of organizations and implemented incremental management innovation, such as, the application of entrepreneurial-oriented managers' behavior, at the level of observed organizations. Management innovation is the difference in the form, quality, or state over time of the management activities in an organization, where a change is a novel or unprecedented departure from the past [24, 49] of an organization or the whole business sector. Until now, this type of innovation was analyzed from different aspects [23, 29, 48], but it still represents an insufficiently analyzed empirical category $[6,39]$ which should not be neglected due to positive effects it has on business performance. Such poor attention of public research aimed at innovation in management is unjustifiable. Today, in the modern business environment faces a transition from a knowledge based economy, to an economy based on creativity. This raises the necessity of implementing novel innovations, to insure organizations can still be leaders in the market [11, p. 17]. As such, innovation in management is a significant driver of efficient and effective business based on the application of new ways of doing business which results in the growth of business performance $[6,23]$ and maintains a competitive advantage.

The orientation of the research is focused on identifying the external and internal context of major organizational innovation systems within the territory of the Republic of Serbia. The external context is analyzed through the impact of turbulent competitive developments, technological progress, changes concerning consumers and legislation. This is one of the possible classifications of external factors according to Bourgeois and Eisenhardt (1988). The internal context of innovation is seen through an implemented incremental management innovation, such as, entrepreneurial-oriented management behavior. With the proper institutional framework in place, the necessary incentives are created in order to foster productive entrepreneurial activity which, then, in general, serves as a catalyst to greater long-term growth [18, p. 73]. The difference between levels of innovation within organizations that belong to the sector of large organizations was also observed from the perspective of selected characteristics, such as: number of employees, the amount of operating income and operating assets.

Emphasis was placed on large organizational systems because theory and practice, in terms of business innovation, have at been given precedence, to small and medium-sized organizations and only more recently, to large business systems. Large organizational systems whose operations are geographically dislocated have global access to information and resources, which provides a basis for innovative ideas and enables usage of more modern equipment and greater expertise. On the basis of various theoretical points of view, some of the criteria in favor of greater innovation within large organizational systems [4, p. 134], [41, p. 213], [44, p. 3] 
are: Investment into research and development activities in proportion to the growth of organization; as the organization grows, research and development productivity grows thus accordingly; higher return on investment within those organizations whose fixed costs of innovation are allocated to higher sales volumes; lower risk regarding the implementation of innovative activities; possibility of applying economies of scale and width during innovation production. However, some studies suggest a more frequent failure in attempting innovation implementation within large organizations, often leading to engagement of consulting organizations that carry out market analysis, identify new or unmet needs, generate promising ideas and transform them into working prototypes [2].

\section{Literature Review}

Innovation in a broader sense represents a profitable use of novelties in the form of new technologies, products and services, organizational, technical and socioeconomic solutions $[32$, p. 6], as well as, challenges from the environment. That emphasizes the importance of the interaction of innovative activities of an organization within the environment, as the use of external sources leads to the implementation of new concepts of creativity and know-how in organizations [34, p. 528]. Lately, greater attention has been devoted to the role of management as a rational category in the implementation of innovation, because they lead to higher productivity, better quality of satisfaction of clients' needs [26, 37], growth efficiency, effectiveness, and achievement of sustainable performance, in order to achieve long-term competitive advantage. Therefore, we can introduce a new category of open management innovation that will enable systematic encouragement of research and a wide range of internal and external sources of innovation opportunities, integrating them with capabilities of the organization and widespread usage of these possibilities, using a number of communication channels [52, p. 377].

From the perspective of innovation, management activity can be seen as a process for creating innovation throughout the whole chain of operations at the micro and/or macro levels, which allows participants, individuals, entrepreneurs and organizations to produce specific and novel results $[36, \mathrm{p}$. 6]. Coordinating creative and productive resources is necessary during this process, including financial resources, technological artifacts and human/social capital [17]. The goal is to create organizational systems that support cooperation and learning, to implement management practices focused on business processes based on continuous improvement of products, services, processes and employees' accomplishments, aiming at customer satisfaction and organizations' survival [3, p. 473]. 
Innovation in management can be defined as the process of generating and implementing management practices, processes, structures and techniques that are new and focused on improving organizational goals [6, p. 829]. Throughout the process of style transformation and the fundamental principles of contemporary business management, organizational changes are implemented into existing or new operational and production activities [31]. This leads to the formation of a new business model with the goal of successful conversion of existing input into the desired output while taking time, cost and quality into account. Within their management system, organizations can implement organizational changes of greater or lesser degree of innovation through implementing incremental innovation in order to keep the current vitality of an organization, and radical ones with the aim of achieving business vitality in the future [16]. Convergent changes lead to minimal changes in business management, similar to the way it was done in the past, while the revolutionary ones imply parallel changes in strategy, structure, systems and culture of the organization, leading to a radically new way of doing business [5, p. 4]. According to Lambić [30, p. 146] revolutionary changes in organizational activities can result in the introduction of new production processes and new ways of creating original technologies and products. The ultimate goal of these changes is the implementation of a new business model, which means finding new business logic and creating new value for stakeholders through income generation and eventually defining new propositions for consumers, suppliers and business partners [9, p. 464].

In order for organizations to survive in today's business environment, they must constantly innovate in their practices and business behaviors [38, p. 291] through the implementation of entrepreneurial management perspectives. This involves radical changes and demands innovation and creation, either bringing an entirely new market into existence or enhancing an existing market in a significant way [46, p. 160]. Organizations cannot be successful, in the long term, without people who possess the characteristics of entrepreneurs; also, organizations cannot be successful if individuals are entrepreneurial, but the conditions within the organizations are not established, to promote entrepreneurship or even hinders the entrepreneurial actions of employees [19, p. 128]. The main task of a manager is to establish a strong organizational culture for implementation of internal innovation, which is possible through promotion of continuous learning and establishing new views that encourage formal and informal collaboration of employees [15, p. 359]. Innovative organizational culture needs to encourage team spirit as well since organizing employees into teams enables them to widen their skills and perspectives, encourages the emergence of common ideas and common responsibility which leads to successful transformation of ideas into new products [8]. An entrepreneurial-minded manager needs to establish a sustainable work environment where employees can meet the obligations and objectives set by the principle of collaboration [1, 40,45]. This is done for the sake of forming the information base by creating social networks that use successful information processing [28, p. 200] as a platform for making optimal decisions. Managers 
need to make business decisions that are going to meet situational changes; they have to accept the contradictory forces of the environment and take them into consideration, which points to the compilation of a broad base of information. This database can be characterized as complex, as it includes a large number of quantitative, qualitative, financial and non-financial information [22, p. 470], which is mutually differentiated and may lead to different interactions, to new combinations that form alternative decisions. Thus, one has to choose sources carefully and know how to make optimal decisions that will include novelties in business management.

\section{Research Methodology}

The research was conducted by application of the questionnaire method. The questionnaire consisted of three sections with a total of 37 questions concerning fluctuations from the external environment, entrepreneurial-oriented behavior of managers and innovation within organizations. Within each part of the questionnaire, there were questions in the form of statements, to which the management was required to respond expressing the degree of agreement with the aforementioned statements, according to the Likert scale, from 1 to 5 . The first part of the questionnaire is a set of customized questions about the analysis of turbulent external environment [7]. The second part includes a scale of the entrepreneurially oriented behavior of managers, which is structured on the basis of different authors on managers' innovative behavior [10, 25, 27, 47, 51]. The last part of the questionnaire includes a scale for the assessment of organizations' innovation, which was examined through a number of innovations that the organization accepted and produced [13, 21, 43]. Reliability of the statements was analyzed by the Cronbach's Alpha coefficient. The value of this coefficient for the questionnaire is 0.8 , indicating the very good reliability of the scale, as well as the very good internal coherence of the statements in the questionnaire because the acceptable value of this ratio is above 0.7 [35].

In addition to using the information base created through the questionnaire method, the data from financial statements for 2012 and 2013 were compared in order to analyze the existence or non-existence of differences in the degree of innovation depending on the number of employees, values of operating incomes and operating assets, as well as the development trend of the mentioned variables.

We interviewed the management of organizations categorized as large legal entities in the Republic of Serbia. According to the Law in Accounting and Auditing (Official Gazette of RS, no. 46/2006, 111/2009, 99/2011, 062/2013), [50] large legal entities are considered to be the ones that meet at least two of the following criteria on the date of giving their financial statements: 1) the average number of employees in the year for which the report is submitted is over 250;2) 
the annual revenue exceeds $10,000,000$ euros, equivalent in dinars; 3 ) the average value of operating assets is over 5,000,000 euros, equivalent in dinars.

The target group was managers of different levels, who we define as individuals on a formal position who are responsible for the work of other employees and the usage of resources, mainly financial [12, p. 264]. Questionnaires were distributed to the e-mail addresses of the management of 70 large legal entities in the Republic of Serbia and we obtained the responses from the management of 50 large organizations.

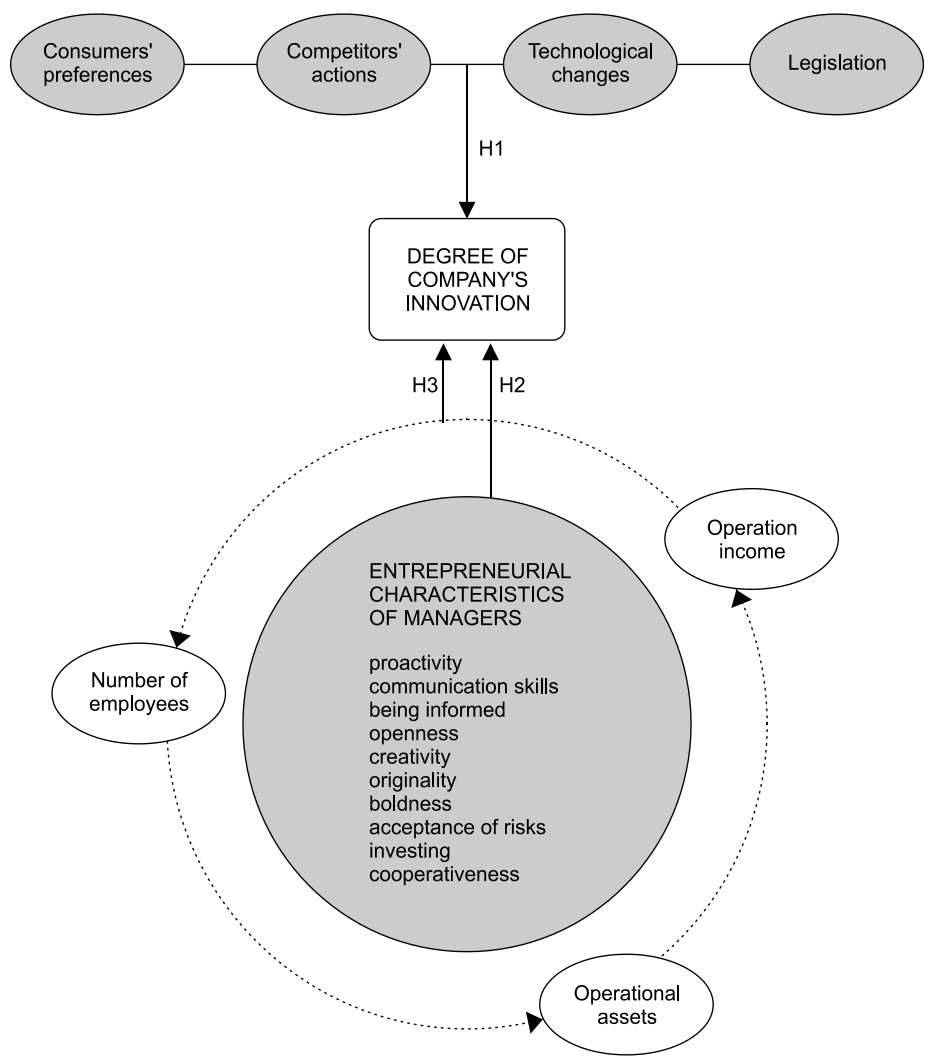

Figure 1

Conceptual framework

Based upon the ruling attitudes in this area and the research orientation that was set, a conceptual framework of the research was formed and these hypotheses:

H1: There is a difference in the degree of innovation of large organizational systems depending on the fluctuations of external factors.

H2: Entrepreneurial nature of managing behavior positively affects the degree of innovation of large organizational systems. 
H3: A higher degree of innovation is present in large organizational systems with a higher average number of employees and greater value of annual revenue and business property.

Parametric and non-parametric statistical methods were used when testing the previously set hypothesis, using the software package, SPSS 20.0. The first hypothesis was tested by MANOVA. Testing of hypothesis $\mathrm{H} 2$, was conducted using the correlation analysis of Spearman coefficient of ranking. Finally, the last hypothesis was tested by a combination of ANOVA and the Mann-Whitney test.

\section{Empirical Results}

We carried out the analysis of turbulent changes in external factors that determine institutional business framework and influence organizations' innovation. The difference in innovation depending on the influence of external factors, both isolated instances and those interacting were analyzed by MANOVA.

Table 1

Multifactor analysis of variance

\begin{tabular}{|c|c|c|c|c|c|c|}
\hline $\begin{array}{c}\text { Fluctuations of external } \\
\text { factors }\end{array}$ & $\begin{array}{c}\text { Type III } \\
\text { Sum of } \\
\text { Squares } \\
\end{array}$ & Df & $\begin{array}{l}\text { Mean } \\
\text { Square }\end{array}$ & $\mathbf{F}$ & Sig & $\begin{array}{c}\text { Partial } \\
\text { Eta } \\
\text { Squared } \\
\end{array}$ \\
\hline $\begin{array}{l}\text { Consumers often change } \\
\text { their preferences within } \\
\text { your line of work }\end{array}$ & 16.637 & 3 & 5.546 & 2.893 & 0.124 & 0.591 \\
\hline $\begin{array}{l}\text { Your consumers tend to } \\
\text { constantly seek new } \\
\text { products or services }\end{array}$ & 28.667 & 2 & 14.333 & 7.478 & 0.023 & 0.714 \\
\hline $\begin{array}{l}\text { Competitive environment } \\
\text { is turbulent within your } \\
\text { line of work }\end{array}$ & 0.500 & 2 & 0.250 & 0.130 & 0.880 & 0.042 \\
\hline $\begin{array}{l}\text { Technology changes in } \\
\text { industry are significant }\end{array}$ & 6.184 & 3 & 2.061 & 1.076 & 0.427 & 0.350 \\
\hline $\begin{array}{l}\text { Within your line of work } \\
\text { innovative activity is } \\
\text { regulated by laws, which } \\
\text { often change }\end{array}$ & 9.955 & 3 & 3.318 & 1.731 & 0.260 & 0.464 \\
\hline
\end{tabular}

Source: Authors' analysis

Individually observed, the impact of every external factor on the innovation of organizations has pointed out that statistically significant effects on innovation are caused only by the consumers who constantly strive to find new products and services $(\mathrm{F}=7.478$, Sig. $=0.023)$. The magnitude of the impact is measured by the Partial Eta Squared coefficient. According to the Cohen's criterion [20], the size of 
the resulting coefficient speaks about the great influence of consumers who constantly strive to find new products and services on innovation (coefficient greater than 0.14 , and is 0.714 ). Large organizational systems which cater for a group of consumers constantly strive to purchase new products and services do innovate more than the organizational system which serves consumers whose needs and wishes do not change very often. By introducing new products in accordance with unmet customer needs, the company is gaining customers' confidence, necessary for company's market success [14]. When conducting subsequent Tukey HSD test, surveyed large legal entities are divided into five groups, i.e. organizations which consider the claim that their customers tend to constantly find new products and services to be: true, partially true, neither true nor false, partly false and false.

Table 2

The Tukey HSD test

Dependent variable: Degree of company's innovation

\begin{tabular}{|c|c|c|c|c|c|c|}
\hline \multirow{2}{*}{\multicolumn{2}{|c|}{$\begin{array}{c}\text { Your consumers } \\
\text { constantly strive to } \\
\text { find new products and } \\
\text { services }\end{array}$}} & \multirow{3}{*}{$\begin{array}{c}\begin{array}{c}\text { Mean } \\
\text { Difference }\end{array} \\
-1.83\end{array}$} & \multirow{3}{*}{$\begin{array}{l}\text { Std. } \\
\text { Error } \\
0.799 \\
\end{array}$} & \multirow{3}{*}{$\begin{array}{c}\text { Sig } \\
0.264 \\
\end{array}$} & \multicolumn{2}{|c|}{$\begin{array}{l}\text { 95\% Confidence } \\
\text { Interval }\end{array}$} \\
\hline & & & & & \multirow{2}{*}{$\begin{array}{r}\text { Lower } \\
\text { bound }\end{array}$} & \multirow{2}{*}{$\begin{array}{c}\begin{array}{c}\text { Upper } \\
\text { bound }\end{array} \\
1.16\end{array}$} \\
\hline 1 & 2 & & & & & \\
\hline (true) & 3 & -2.67 & 0.715 & 0.051 & -5.35 & 0.02 \\
\hline & 4 & -2.27 & 0.644 & 0.065 & -4.68 & 0.15 \\
\hline & 5 & $-3.67 *$ & 0.770 & 0.017 & -6.56 & -0.78 \\
\hline \multirow{4}{*}{$\begin{array}{l}2 \\
\text { (partially } \\
\text { true) }\end{array}$} & 1 & 1.83 & 0.799 & 0.264 & -1.16 & 4.83 \\
\hline & 3 & -0.83 & 0.715 & 0.770 & -3.52 & 1.85 \\
\hline & 4 & -0.43 & 0.644 & 0.956 & -2.85 & 1.58 \\
\hline & 5 & -1.83 & 0.770 & 0.239 & -4.72 & 1.06 \\
\hline \multirow{4}{*}{$\begin{array}{l}3 \\
\text { (neither } \\
\text { true nor } \\
\text { false) }\end{array}$} & 1 & 2.67 & 0.715 & 0.051 & -0.02 & 5.35 \\
\hline & 2 & 0.83 & 0.715 & 0.770 & -1.85 & 3.52 \\
\hline & 4 & 0.40 & 0.536 & 0.937 & -1.61 & 2.41 \\
\hline & 5 & -1.00 & 0.682 & 0.615 & -3.56 & 1.56 \\
\hline \multirow{4}{*}{$\begin{array}{l}4 \\
\text { (partly } \\
\text { false) }\end{array}$} & 1 & 2.27 & 0.644 & 0.065 & -0.15 & 4.68 \\
\hline & 2 & 0.43 & 0.644 & 0.956 & -1.98 & 2.85 \\
\hline & 3 & -0.40 & 0.536 & 0.937 & -2.41 & 1.61 \\
\hline & 5 & -1.40 & 0.608 & 0.261 & -3.68 & 0.88 \\
\hline \multirow{4}{*}{$\begin{array}{l}5 \\
\text { (false) }\end{array}$} & 1 & $3.67^{*}$ & 0.770 & 0.017 & 0.78 & 6.56 \\
\hline & 2 & 1.83 & 0.770 & 0.239 & -1.06 & 4.72 \\
\hline & 3 & 1.00 & 0.682 & 0.615 & -1.56 & 3.56 \\
\hline & 4 & 1.40 & 0.608 & 0.261 & -0.88 & 3.68 \\
\hline
\end{tabular}

*. The mean difference is significant at the 0.05 level. 
The results of subsequent tests support the conclusion that there is a difference in the level of innovation in organizational systems where consumers tend to constantly seek new products and services and those organizational systems where consumers do not tend to do that. Top management organizations that serve innovative intensive consumers, from the perspective of product innovation and service innovation, should continuously innovate all levels of business, in order to allow placement of the new products and services that comply with the changes in consumer demands.

In addition to the analysis of the external context, we also conducted an analysis of the internal context of an organization, from the angle of connection between the application of the novel entrepreneurial oriented managing behavior, as a form of management innovation and the degree of innovation of large organizational systems. For this purpose, we used the Spearman rank correlation whose results are shown in the following table.

Table 3

The Spearman rank correlation

\begin{tabular}{|l|l|c|}
\hline \multicolumn{1}{|c|}{$\begin{array}{c}\text { Statements describing entrepreneurial behavior of } \\
\text { managers }\end{array}$} & $\begin{array}{c}\text { Degree of company's } \\
\text { innovation }\end{array}$ \\
\hline Statements describing entrepreneurial behavior of managers & $\rho$ & $\mathbf{0 . 6 7 4} * *$ \\
\hline $\begin{array}{l}\text { Representing the organization to wider public in an } \\
\text { innovative way }\end{array}$ & $\rho$ & $\mathbf{0 . 5 6 0} * *$ \\
\hline Implementing innovations into the business plan & $\rho$ & $\mathbf{0 . 3 0 0} *$ \\
\hline Constantly spreading managers' social network & $\rho$ & $\mathbf{0 . 2 8 8}$ \\
\hline Frequent and good relations with business partners & $\rho$ & $\mathbf{0 . 4 3 9} * *$ \\
\hline Constant search for innovation ideas & $\rho$ & $\mathbf{0 . 3 0 3} *$ \\
\hline $\begin{array}{l}\text { Emphasizing their own originality and creativity together } \\
\text { with realization of tangible results }\end{array}$ & $\rho$ & -0.066 \\
\hline $\begin{array}{l}\text { Application of bold and aggressive business attitude in order } \\
\text { to use potentials to the maximum }\end{array}$ & $\rho$ & $\mathbf{0 . 4 0 5 * *}$ \\
\hline $\begin{array}{l}\text { Timely and successful conflict resolution among the } \\
\text { employees and team members }\end{array}$ & $\rho$ & $\mathbf{0 . 4 5 9 * *}$ \\
\hline $\begin{array}{l}\text { Giving constructive solutions in case of a delay during } \\
\text { project implementation }\end{array}$ & $\rho$ & 0.167 \\
\hline $\begin{array}{l}\text { Allocating different kinds of resources to realization of } \\
\text { business activities }\end{array}$ & $\rho$ & $\mathbf{0 . 4 3 5 * *}$ \\
*. Correlation is significant at the 0.05 level (2-tailed). \\
**. Correlation is significant at the 0.01 level (2-tailed).
\end{tabular}

The results indicate the existence of a strong and statistically significant relation between the managers who represent the organization in an innovative manner and the degree of innovation for the whole organization $(\rho=0.674$; Sig. $=0.000)$. In addition to strong relation, statistically significant relation of the medium intensity has been isolated between innovation of organizations and the managers who: 
- Constantly encourage implementation of innovation in business plans with the aim of increasing customer values, satisfaction of existing customers and attracting the new customers $(\rho=0.560$; Sig. $=0.000)$

- Use their own creative potential to the maximum with the constant search for ideas for innovation $(\rho=0.439$; Sig. $=0.001)$

- Consider themselves to be original and creative people $(\rho=0.303$; Sig. $=$ 0. 033)

- Successfully resolve conflicts between employees and team members ( $\rho$ $=0.405 ;$ Sig. $=0.004$ )

- Provide constructive solutions in the case of delay during project implementation $(\rho=0.459$; Sig. $=0.001)$

- $\quad$ Negotiate and encourage cooperation with business partners $(\rho=0.435$; Sig. $=0.002$ )

Statistically, the significant relation of low intensity was confirmed between managers who constantly widen their social network of contacts $(\rho=0.280$; Sig. $=$ $0.049)$, have good relationships with customers and business partners $(\rho=0.288$; Sig. $=0.043)$ and the degree of innovation within the organization.

Analysis of internal characteristics at the level of the whole organization was conducted through ANOVA and Mann-Whitney test. Depending on the isolated characteristics and performance of organizations, we conducted an analysis of the differences in innovation degrees in large organizational systems, as shown in the table below.

Table 4

Differences in innovation of an organization according to isolated characteristics and performance of companies

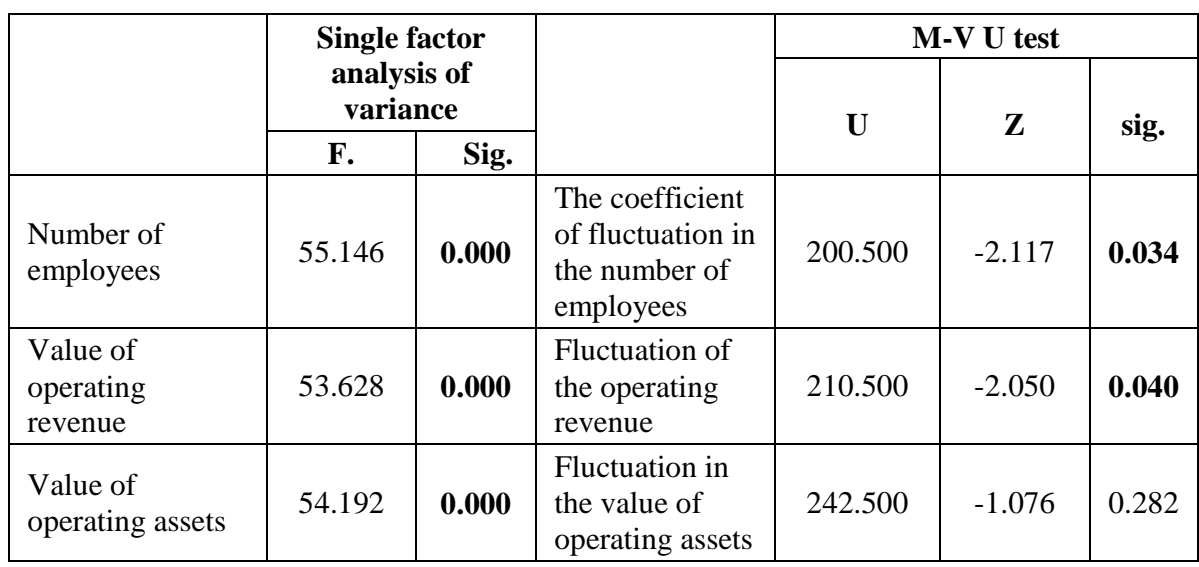

Source: The authors' analysis 
One of the important criteria of business is personnel potential, both in qualitative and quantitative terms. Application of ANOVA showed the existence of differences in the innovation of organizations depending on the number of employees $(F=55.146$, Sig. $=0.000)$. The project included detailed analysis using the Tukey HSD test since the sample consisted of large organizations whose number of employees ranged from 48 employees to 4,701 . There was a difference in the level of innovation among organizations with 48 to 300 employees $(\mathrm{M}=$ 14.5263; $\mathrm{SD}=2.52473)$, organizations employing 300 to 700 employees $(\mathrm{M}=$ $18.7143 ; \mathrm{SD}=0.91387$ ), and those with over 700 employees $(\mathrm{AS}=20.0000 ; \mathrm{SD}=$ 0.00000 ). Organizations that have the highest number of employees also have the greatest opportunities for improving innovation by motivating their employees for creative thinking and more innovative implementation of business tasks. The trend in the number of employees and the influence of such developments on the existence of differences in the innovation of organizations is significant. Application of the Mann-Whitney test has shown the existence of differences (Mann-Whitney = 200.500; Asymp. Sig. $=0.034$ ) when considering the level of organizations' innovation, depending on the changes in the number of employees. Based on median values of the organizations that had a growth in the number of employees or in which the number of employees remained unchanged (Median = 20.0000), those proved to be more innovative in comparison to the organizations which had a reduction in the number of employees (median $=17.0000$ ). Those organizations that have modernized their human potential, both in qualitative and quantitative terms, record greater innovation than others that have reduced their staff potential through dismissal or employees' retirement.

By using ANOVA we determined the existence of differences in innovation in organizations when it comes to the value of operating income $(\mathrm{F}=53.628$; $\mathrm{Sig}$. $=$ 0.000). Results of the Tukey HSD test revealed a significant difference (Sig. = 0.000 ) between the degree of innovation of organizations with the value of operating income ranging from $3,489,183$ to $26,168,876$ euros $(\mathrm{M}=14.3889$; SD $=2.52374$ ), organizations with medium business revenue of between $26,168,876$ and 95,952,547 euros $(\mathrm{M}=18.8947 ; \mathrm{SD}=1.04853)$ and organizations with the highest value of operating income, 95,952,547 to 558,269,364 euros ( $\mathrm{M}=$ 20.0000; SD $=0.00000$ ). The results indicate that organizations with a higher value of operating income have greater opportunities to invest in innovation. The dynamic category of operating income was also discussed, i.e. influence of its fluctuation on existence or non-existence of differences in innovation. Nonparametric Mann-Whitney test was conducted, which showed the existence of differences (Mann-Whitney $=210.500$; Asymp. Sig. $=0.040$ ) in the degree of innovation, depending on the fluctuations of operating income. The value of the median indicates that organizations that had a decline in the value of operating income (Median $=20.0000$ ) are more innovative in comparison to the organizations which had growth of operating income (Median $=17.0000$ ). Obtained results can be explained by the attitude of the management in organizations which have been declining in revenue and their ability to come up 
with new ways of doing business, eliminate the negative trend and move forward in business. On the other hand, strong organizations that continuously generate revenue growth can become complacent due to their previous business success and therefore ignore innovation.

Application of ANOVA showed the existence of differences in innovation depending on the value of operating assets $(F=54.192$; Sig. $=0.000)$. By applying the Tukey HSD test we found differences in innovation between organizations that have a minimum value of the operating assets, i.e. $5,233,775$ to $26,168,876$ euros $(\mathrm{M}=14.5263$, sd $=2.52473)$ and organizations that have medium value of operating assets, i.e. $26,168,876$ to $200,628,053$ euros $(\mathrm{M}=18.8000 ; \mathrm{SD}=$ 0.94112 ), as well as those organizations that have the highest value of operating assets ranging from $200,628,053$ to $1,334,612,700$ euros $(\mathrm{M}=20.0000 ; \mathrm{SD}=$ .00000). It can be concluded that organizations that have the greatest levels of operating assets are also the most innovative. In relation to the fluctuations of operating assets by applying the nonparametric Mann-Whitney test, it was established that there was no statistically significant difference in the innovation of organizations depending on the fluctuation of operating assets (Mann-Whitney $=242.500$; Asymp. Sig. = 0.282).

\section{Conclusions}

The objective of the conducted research is focused on providing answers to the following question: How do external market trends, together with the internal characteristics of the organization and managing the behavior of managers, affect innovation in large organizational systems? Statistically significant and separated features of markets, management, and internal organization represent a potential list of incentive factors when innovating in the entire organization.

Depending on the fluctuation of competitive organizations, technological changes, consumer needs and preferences, as well as, legislation, the difference in innovation occurred only between those organizations that serve innovation oriented consumers and those that do not serve such customer groups. Therefore, the hypothesis H1, is only partially confirmed. The result is logical because in modern business environments consumers are among the most important external parties that influence long-term survival of the organization. Meeting their needs, according to the principle of offering the highest customer value, encourages innovation of business processes.

A key role in creation, transfer and implementation of all types of innovation lies in the business behavior of the top management and in the chosen management style. The results of empirical studies have indicated that such management that creates entrepreneurial organizational culture fosters a greater degree of innovation. The previous statement is supported by the economists who believe that organizations whose organizational context supports new thinking, freedom of internal change agents increase [6, p. 834] influencing creation of new ideas and their successful exploitation [33, p. 301], all for the sake of obtaining 
innovation. Greater freedom of managers should be transferred to the employee's at all hierarchical levels, in order to ensure a broader base of potential ideas that will further be analyzed and filtered in accordance with the possibilities of an organization, time and market trends. This is confirmed by the hypothesis $\mathrm{H} 2$.

If we observe the value of the operating income, the results of the empirical research lead to the conclusion that large entities whose operating income value is over 95,952,547 euros are more innovative, because greater financial possibilities offer better opportunities in terms of innovation. Thus, they can maintain the current trend of growth or achieve sustainable competitive advantage. We obtained somewhat different results taking into account the aspect of fluctuations of the value of business revenue. These results showed that organizations that have met a decline of operational income are more innovative. The abovementioned results have led to new conclusions - organizations which are faced with deteriorating business, invest more in the innovation of products, services and processes, in an effort to improve the deteriorating business processes. The more innovative organizations are those that employ more than 700 employees. The obtained result can be confirmed by some economists who believe that large legal entities are more innovative due to greater financial opportunities since those can facilitate greater personnel resources. Higher Personnel resources provide higher creative potential and better diversification of the risks related to the implementation of various innovations. The empirical findings confirm Schumpeter's traditional hypothesis, stating that large organizations are more innovative than smaller ones. Operation Asset values are one of the main criteria for doing business. This criterion indicates differences in innovation between organizations whose operating assets greater than 200,628,053 euros and those organizations that have lower operating assets value. A series of previously presented conclusions are confirmed by the hypothesis $\mathrm{H} 3$.

\section{References}

[1] Akhtar, S.: Human Capital Utilization through Effective HRM Practices, Middle-East Journal of Scientific Research, 8 (2) 2011, pp. 434-439

[2] Altringer, B.: A New Model of Innovation in Big Companies, Harward Business Review, https://hbr.org/2013/11/a-new-model-for-innovation-inbig-companies/, 2013

[3] Anderson, J. C., Rungtusanatham, M. and Schroeder, R. G.: A Theory of Quality Management Underlying the Deming Management Method, Academy of Management Review, 19 (3) 1994, pp. 472-509

[4] Aranda, D. A., Rata, B. M. and Duarte, A. R.: Innovation and Firm Size: an Empirical Study for Spanish Engineering Consulting Companies, European Journal of Innovation Management, 4 (3) 2001, pp. 133-142

[5] Balogun, J. and Hope Hailey, V.: Exploring Strategic Change, Prentice Hall, England, 2008 
[6] Birkinshaw, J., Hamel, G. and Mol, M. J.: Management Innovation, Academy of Management Review, 33 (4) 2008, pp. 825-845

[7] Bourgeois, L. J., Eisenhardt, K. M.: Strategic Decision Processes in High Velocity Environments: Four Cases in the Microcomputer Industry, Management Science, 34, 1988, pp. 816-835

[8] Brown, T.: Change by Design: How Design Thinking Transforms Organizations and Inspires Innovation, HarperCollins Publisher, New York, 2009

[9] Casadesus-Masanell, R. and Zhu, F.: Business Model Innovation and Competitive Imitation: The Case of Sponsor-based Business Models. Strategic Management Journal, 34 (4) 2013, pp. 464-482

[10] Chakrabarti, A. K.: The Role of Champion in Product Innovation, California Management Review, 17 (2) 1974, pp. 58-62

[11] Chaniadi, F.: Innovative Management of Innovation Management, Manchester Bussines School, Manchester, 2014

[12] Coopey, J., Keegan, O. and Emler, N.: Managers' Innovations and the Structuration of Organizations, Journal of Management Studies, 35 (3) 1998, pp. 263-284

[13] Damanpour, F.: Organizational Innovation: A Meta Analysis of Effects of Determinants and Moderators, Academy of Management Journal, 34, 1991, pp. 555-590

[14] Dejanović, M. A., Nikolić, T. S. and Stanković, J.: Integral Model of Strategic Management: Identification of Potential Synergies, Acta Polytechnica Hungarica, 12 (8) 2015, pp. 115-133

[15] Denham, J. and Kaberon, R.: Culture Is King: How Culture Contributes to Innovation, Journal of Product Innovation Management, 29 (3) 2012, pp. 358-360

[16] Diaz Fernandez, M., Pasamar Reyes, S. and Valle Cabrera, R.: Are Ambidextrous Intellectual Capital and HRM Needed for an Ambidextrous Learning, Working paper Series BOM 12.01, http://www.upo.es/serv/bib/wpboam/wpboam1201.pdf, 2012

[17] Dodgson, M., Gann, D. and Salter, A.: The Management of Technological Innovation, Oxford University Press, USA, 2008

[18] Dove, J.: The effect of Judicial Independence on Entrepreneurship in the US States, Economic Systems, 39, 2015, pp. 72-96

[19] Dubravska, M., Mura, L., Kotulič, R. and Novotny, J: Internationalization of Entrepreneurship - Motivating Factors: Case Study of the Slovak Republic, Acta Polytechnica Hungarica, 12 (5) 2015, pp. 121-133 
[20] Ellis, P. D.: The Essential Guide to Effect Sizes: An Introduction to Statistical Power, Meta-Analysis and the Interpretation of Research Results, Cambridge University Press, Cambridge, 2010

[21] Garcia, R., Calantone, R.: A Critical Look at Technological Innovation Typology and Innovativeness Terminology: a Literature Review, Journal of Product Innovation Management, 19 (2) 2002, pp. 110-132

[22] Hanh, T., Preuss, L., Pinkse, J. and Figge, F.: Cognitive Frames in Corporate Sustainability: Managerial Sensemaking with Paradoxical and business Case Frame, Academy of Management Review, 39 (4) 2014, pp. 463-487

[23] Hamel, G.: The Why, What, and How of Management Innovation (cover story), Harvard Business Review, 84 (2) 2006, pp. $72-84$

[24] Hargrave, T. and Van de Ven, A.: A collective action model of institutional innovation, Academy of Management Review, 31, 2006, pp. 864-888

[25] Howell, J., Higgins, C.: Champions of Technological Innovation, Administrative Science Quarterly, 35, 1990, pp. 317-341

[26] Ichniowski, C., Shaw, K., Prennushi, G.: The Effects of Human Resource Management Practices on Productivity: a Study of Steel Finishing Lines, American Economic Review, 87 (3) 1997, pp. 291-313

[27] Keller, R. T., Holland, W. E.: Communicators and Innovators in Research and Development Organizations, Academy of Management Journal, 26 (4) 1983, pp. 66-74

[28] Kleinschmidt, E., Brentani, U. and Salomo, S.: Information Processing and Firm-Internal Environment Contingencies: Performance Impact on Global New Product Development, Creativity and Innovation Management, 19 (3) 2010, pp. 200-218

[29] Kossek, E. E.: The Acceptance of Human Resource Innovation by Multiple Constituencies. Personnel Psychology, 42, 1989, pp. 263-280

[30] Lambić, M.: Inženjerstvo i inovacije, Tehnički fakultet Mihajlo Pupin, Zrenjanin, 1996

[31] Mol, J. M., and Birkinshaw, J.: The Sources of Management Innovation: When Firms Introduce New Management Practices, Journal of Business Research, 62 (12) 2009, pp. 1269-1280

[32] Морозов, Ю., П.: Иновационный менеджмент, юнити-дана, Москва, 2000

[33] O'Regan, N. and Ghobadian, A.: Innovation in NTBFs: Does Leadership Really Matter?, International Entrepreneurship and Management Journal, 2 (2) 2006, pp. 299-314 
[34] Ortt, J. R. and Van der Duin, A. P.: The Evolution of Innovation Management Towards Contextual Innovation, European Journal of Innovation Management, 11 (4) 2008, pp. 522-538

[35] Pallant, J.: SPSS priručnik za preživljavanje, 4 izdanje (prevod): Mikro knjiga, Beograd, 2011

[36] Pervaiz, K. A. and Charles, D. S.: Innovation Management: Context, Strategies, Systems and Processes. Pearson Education Limited, England, 2010

[37] Pil, F. K. and MacDuffie, J. P.: The Adoption of High Involvement Work Practices, Industrial Relations, 35 (3) 1996, pp. 423-455

[38] Potocan, V., Nedelko, Z. and Mulej, M.: Influence of Organizational Factors on Management Tools Usage in Slovenian Organizations. Inzinerine Ekonomika-Engineering Economics, 23 (3) 2012, pp. 291-300

[39] Radu, O. M.: Stimulating Firm Innovativeness: Probing the Interrelations between Managerial and Organizational Determinants, Erasmus University, Rotterdam, 2012

[40] Ramezani, Z. N., Khabiri, M., Alvani, S. M. and Tondnevis, F.: Use of Mintzberg's Model of Managerial Roles to Evaluate Sports Federations Managers of Iran, Middle-East Journal of Scientific Research, 10 (5) 2011, pp. $559-564$

[41] Schilling, M. A.: Strategic Management of Technological Innovation, McGraw-Hill, New York, 2010

[42] Smith, K. G., Collins, C. J. and Clark, K. D.: Existing Knowledge, Knowledge Creation Capability, and the Rate of New Product in Production in High-technology Firms, Academy of Management Journal, 48, 2005, pp. 346-357

[43] Subramanian, A., Nilakanta, S.: Organizational Innovativeness: Exploring the Relationship between Organizational Determinants of Innovation, Types of Innovations, and Measures of Organizational Performance, Omega, 24 (6) 1996, pp. 631-647

[44] Symeonidis, G.: Innovation, Firm Size and Market Structure, OECD Economics Department Working Papers No. 161, http://dx.doi.org/10.1787/603802238336, 1996

[45] Tengblad, S.: Is there a New Managerial Work? A Comparison with Henry Mintzberg's Classic Study 30 Years Later, Journal of Management Studies, 43, 2006, pp. 1437-1461

[46] Troilo, M.: Legal Institutions and High-Growth Aspiration Entrepreneurship, Economic Systems, 35, 2011, pp. 158-175 
[47] Tushman, M. L., Scanlan, T. J.: Characteristics and External Orientations of Boundary Spanning Individuals, Academy of Management Journal, 24 (1) 1981, pp. $83-98$

[48] Vaccaro, G. I., Jansen, J. P .J., Van Den Bosch, A. J. F. and Volberda, W. H.: Management Innovation and Leadership: The Moderating Role of Organizational Size, Journal of Management Studies, 49 (1) 2012, pp. 2851

[49] Vande Ven, A. H. and Poole, M. S.: Explaining Development and Change in Organizations, Academy of Management Review, 20, 1995, pp. 510-540

[50] Law on Accounting and Auditing, the Official Gazette of the Republic of Serbia no. 62/2013

[51] Walter, A., Parboteeah, K., Riesenhuber, F., Hoegl, M.: Championship Behaviors and Innovations Success: An Empirical Investigation of University Spin-Offs, Journal of Product Innovation Management, 28, 2011, pp. 586-598

[52] Wikhamn, R. B.: Two Different Perspectives on Open Innovation-Libre versus Control, Creativity and Innovation Management, 22 (4) 2013, pp. 375-389 